\title{
MÍDIA CELULAR - PUBLICIDADE E CONSUMO ESTRATIFICADO
}

\section{The mobile media - Stractified advertising and consumption}

\author{
Talvani Lange ${ }^{1}$ \\ Rafael de Tarso Shroeder ${ }^{2}$
}

\section{Resumo}

Neste texto o foco de discussão é o telefone celular como uma ferramenta de comunicação do marketing. Baseado em pesquisa bibliográfica e observação empírica, este estudo exploratório enfatiza alguns aspectos históricos e técnicos do celular. Nós também exploramos novas funções aplicadas a este instrumento, com vistas à compreensão das novas formas de publicidade. Sob um aspecto social e interativo, descrevemos a segmentação estratificada do consumo que também está implícita nestas estratégias de marketing, a partir do telefone celular como mídia.

Palavras-chave: publicidade, mídia celular, marketing, consumo estratificado.

\begin{abstract}
In this text we approach the cell phone as a tool of media in marketing communication. Based on bibliographical research and empirical observation, this exploratory study emphasizes some historical and technique aspects of the cell phone. We also explore new functions applied to this tool, leading to new forms of advertisements. In social and interactive aspect, we describe the segmentation and stratified consumer that is also implicit in these marketing strategies.
\end{abstract}

Key words: advertising, cell media, marketing, stratified consumer.

\section{Resumen}

Esto artículo busca presentar algunos aspectos del uso de los equipos portables de teléfono, el celular, como mídia para la publicidad y para el desarollo de comunicaciones de consumo. Esta posibilidad del celular visto como mídia es resultante de la convergencia

\footnotetext{
${ }^{1}$ Doutor em Ciências da Comunicação pela USP e Mestre em Comunicação pela UMESP. Docente do departamento de Comunicação Social da Universidade Federal do Paraná (UFPR) e Professor do Programa de Pós Graduação em.Sociologia da UFPR

${ }^{2}$ Bacharel em Comunicação Social - Publicidade e Propaganda pela Universidade Federal do Paraná; Formado em Tecnologia em Artes Gráficas pela UTFPR, tem MBA em Gestão Estratégica Empresarial com ênfase em Marketing pela Educon - USP. Coordenador de marketing e comunicação da ONG Aliança Empreendedora.
} 
midiática y de la pentración que estos equipos teinen en las vidas de las personas hoy. Eso implica en otros modos de planear la comunicación para el mercado. Aqui ententamos construir horizontes para comprender esta nueva posibilidad midiática de la publicidad.

Palabras-Clave: mídia, celular, publicidad, consumo.

\section{ASPECTOS INTRODUTÓRIOS E HISTÓRICOS}

Embora o celular faça parte da história do telefone, uma vez que é, do ponto de vista físico, uma variação do mesmo, porém ele está mais relacionado à invenção do rádio.

O telefone, criado pelo estudioso escocês Alexander Graham Bell em 1876, foi inspirado no aparelho de telégrafo (1835), no qual mensagens entre pontos distantes poderiam ser transmitidas. Estas informações eram transmitidas em forma de códigos e não de sons.

Graham Bell conseguiu adaptar a tecnologia, transmitindo a voz através de um fio. Porém, os primeiros aparelhos não permitiam falar e ouvir ao mesmo tempo, e este feito só foi obtido mais tarde, com os aperfeiçoamentos introduzidos por Thomas Edison.

Ao mesmo tempo, o alemão Heinrich Hertz conseguiu produzir as primeiras ondas de rádio e, por meio destas, a possibilidade de transmitir informações pelo ar. A descoberta foi fundamental para a invenção do aparelho como meio de comunicação e base para que, em 1914, fosse realizada a primeira ligação telefônica entre dois continentes. Em 1967 foi desenvolvido o telefone sem fio.

Existem rumores de que a idéia básica do serviço celular surgiu em 1940, quando a atriz de Hollywood, Hedy Lamaar ${ }^{3}$ teve a idéia de criar um sistema de rádio através do qual poderia conversar privativamente com outra pessoa, sem interferências, apenas mudando o canal de transmissão.

No entanto, a história oficial é outra - com origem mais recente. O telefone celular teria tido sua primeira utilização pública no dia 3 de Abril de 1973. O responsável foi o pesquisador da Motorola, Martin Cooper, que ligou para um telefone fixo diretamente de uma esquina do centro de Nova Iorque, nos Estados Unidos.

O primeiro aparelho pesava cerca de um quilo $(1 \mathrm{~kg})$ e media por volta de $25 \mathrm{~cm}$ de comprimento por $7 \mathrm{~cm}$ de largura. Sua bateria, porém, em apenas 20 minutos de conversa se esgotava. Na verdade, o celular foi um avanço da tecnologia utilizada em telefones de automóveis. De fato, o produto foi disponibilizado ao mercado só em 1983, quando a

\footnotetext{
${ }^{3}$ Austríaca com nome verdadeiro de Hedwig Kiesler.
} 
própria Motorola lançou o modelo DynaTAC 8000 que, na época, custava cerca de U\$4.000,00 (quatro mil dólares) e mesmo assim já contava com uma lista de espera para a compra.

O telefone celular remete a duas proposições básicas: comunicação instantânea e falar com alguém. A comunicação é bi-direcional e recíproca. Sendo assim, para falar com alguém precisaríamos chegar à sua presença. Isso implica superar distâncias - a pé ou por meio de transporte. Significa também uma coordenação temporal - precisamos estar onde o outro está, no mesmo momento. A escrita resolve o problema de tempo e espaço, mas não o da troca instantânea. O telefone fixo resolve o problema da distância e da troca, mas não o da coordenação de tempo e espaço - se o outro não está, talvez possamos deixar um recado.

Em artigo publicado pela UNB, Hartmut Günther, professor e coordenador do Laboratório de Psicologia Ambiental do Instituto de Psicologia da própria instituição afirma: "Somente o telefone celular, em princípio, nos livra das limitações de tempo e de espaço, permite a comunicação instantânea" (Günther 2005).

Essa possibilidade gerou uma explosão no consumo e, conseqüentemente, surgiram novas empresas que, investindo muito dinheiro tanto em avanços tecnológicos como na estrutura de serviço e na qualidade, possibilitaram o desenvolvimento de um mercado altamente competitivo e promissor. Hoje as concessionárias ou também chamadas operadoras de telefonia estão entre os principais e maiores anunciantes do mercado publicitário. Essas transformações a cada dia surpreendem e modificam a forma de se encarar a tecnologia móvel, e isso é facilmente percebido, principalmente, a partir do momento em que as pessoas passaram a se relacionar freqüentemente com esse produto.

No Brasil, o primeiro celular foi comercializado oficialmente no Rio de Janeiro pela Telerj (subsidiária do Sistema Telebrás, hoje privatizada), em 1990. O valor da habilitação era no mínimo absurdo para os dias atuais: US\$ 22 mil (vinte e dois mil dólares). O sistema, de tecnologia AMPS (Advanced Mobile Phone System ou Sistema Telefônico Móvel Avançado) era ainda analógico, mas permitiu que se repetisse no Brasil a mesma empolgação já vista em outros países. O ganho de escala reduziu os preços das tarifas do serviço e do aparelho. Mas foi a introdução da modalidade de pagamento antecipado, o prépago, em 1998, que popularizou o serviço, tornando-o acessível a grande parte do povo brasileiro.

Hoje são inúmeros os serviços e diferenciais, que vão, desde o envio de mensagens escritas SMS (Short Messaging Service ou Serviço de Envio de Mensagens Curtas) e 
multimídia MMS (Multimedia Messaging Service ou Serviço de Mensagens Multimedia), à recepção de filmes e programas de TV, câmeras digitais, teleconferências, acesso à internet, noticiários, troca de arquivos de computador e a incorporação de sistemas de localização, com a utilização de receptores GPS (Global Positioning System ou Sistema de Posicionamento Global), e inclusive mensagens publicitárias, catálogo de produtos, jogos, entretenimento, mas também a personalização das áreas de visualização como proteções e fundos de telas e os toques (sons) para o celular.

\subsection{Implicações mercadológicas e sociais do produto}

Todos os canais e formas de comunicação mercadológica têm pontos positivos e pontos negativos e também oferecem oportunidades e apresentam limitações, de acordo com a lógica de produção e circulação de mercadorias, a fim de propiciar e/ou manter certa lucratividade dos anunciantes. Nesse ambiente, pode-se citar que as grandes mídias, como a televisão e o rádio, permitem que as mensagens atinjam grande parte do público; a internet, que possibilita interatividade, e outras, as quais, de acordo com a necessidade, condição, custo, público e eficiência, fazem parte da estrutura e das opções nos planos de comunicação, os quais estão, na maioria das vezes, intermediados por agências de publicidade, responsáveis pela elaboração de campanhas integradas, a fim de apontar soluções mercadológicas para seus clientes.

Ações de comunicação/promoção que podem ser concebidas para que a mensagem seja veiculada na mídia de massa e/ou de alta segmentação, para públicos bem selecionados, delimitados por aspectos demográficos e/ou psicográficos, por exemplo.

No entanto, os profissionais perceberam que essa gama de ferramentas e canais promoveu a fragmentação da audiência e aumentou a dificuldade da propaganda de chamar a atenção do público e proporcionar o retorno efetivo e esperado por anunciantes. Estes, a cada dia, buscam formas de controlar e verificar se a mensagem foi recebida e compreendida, ou seja, possibilidades de mensurar o trabalho e corrigir as estratégias. $\mathrm{O}$ desafio para eles está na possibilidade maior de obter segurança, controle e ações personalizadas facilmente adaptáveis, mas que sejam economicamente viáveis. Por outro lado, não apenas as mensagens, mas também o meio e os processos em que ocorre a comunicação apresentam um conjunto complexo de variáveis e que inviabilizam qualquer idéia absoluta de mensuração.

A passagem do século XX ao XXI é marcada por singularidades que tangenciam a 
velocidade da informação e da técnica como elementos agregados às mercadorias e às possibilidades de (in)satisfações do homem junto ao uso e aos valores de troca a ela agregados. Considerando a proposta de uso dos produtos no mercado, o celular, também conhecido como Third screen ou Terceira Tela (depois da televisão e do computador), surge para suprir ${ }^{4}$ (ou, quem sabe, criar?) uma das necessidades do ser humano: nos comunicarmos em qualquer lugar. Grande parte da população mundial, hoje, carrega um aparelho de telefone. Entretanto, sua utilização adquire expressões que escapam à mera tarefa de troca de informações entre interlocutores no tempo e no espaço. O produto pode servir também para contatos profissionais, proteção e segurança de seus familiares e, mais recentemente, para entretenimento e busca por informação. Obviamente devido às questões não só tecnológicas, mas principalmente mercadológicas e de estratificação social, muitos não têm acesso ou não conseguem usufruir desse serviço.

\subsection{O consumo estratificado do celular na sociedade}

Sob a égide da segmentação do mercado e da possibilidade de expansão do capital agregado à evolução tecnológica, os estrategistas de marketing pensam novos usos, ferramentas e aplicabilidades. Isso, considerando também, a variável preço que pode acompanhar o aumento do consumo, promovendo formas de "desnatamento" quanto à acessibilidade aos (considerados) benefícios das novidades nos aparelhos.

Com um conjunto variado de características no produto, a tecnologia permite que diferentes práticas de preços possam ser enquadradas e direcionadas a variados públicos consumidores, de acordo com opções de estilo de vida, classe social, idade, sexo e comportamento, por exemplo. Sob o ponto de vista dos anunciantes, produtores da mercadoria, a estratégia é o fornecimento de um pacote de funcionalidades com preços diferenciados, a fim de atingir cada parcela, considerada como alvo. De certo modo, é uma objetivização do ser humano, pois o uso de tais palavras comumente utilizadas na literatura do pragmatismo mercadológico - alvo, atingir, segmentar (fatiar)

- colaboram para a significação de posicionar o sujeito consumidor como simples objeto dos desejos de expansão de faixas "de abocanhamento" da população economicamente

\footnotetext{
${ }^{4}$ Neste momento poderíamos explorar uma polêmica, envolvendo os teóricos do marketing e da comunicação - O homem é insatisfeito, por natureza, cabendo aos mecanismos do mercado satisfaze-lo? Contudo, não pretendemos explorar tal controvérsia.

${ }^{5} \mathrm{O}$ desnatamento é um conceito utilizado em livros técnicos de marketing e que, resumidamente, pressupõe o percurso e ciclo de vida das mercadorias em um processo de acessibilidade que inicia com classes de maior poder aquisitivo até chegar em classes com menor poder de compra, mediante alterações na variável preço.
} 
ativa em dada área geográfica. Isso numa ferocidade, considerada por alguns "de guerrilha", para se destacar e se impor perante o concorrente, que também quer abocanhar a mesma parcela populacional. Aliás, abocanhar é outro verbo comumente utilizado no meio.

A estratificação social é possibilitada perante a lógica que se inicia do luxo e segue em direção ao lixo. Luxo, quando mediante à inovação da técnica, os produtores permitem que haja o direcionamento dos olhares amorosos da mercadoria àquele consumidor ávido por novidades, no desejo de se diferenciar dos demais, com a possibilidade de aquisição do produto anunciado. Eles chamam isso de mix de produtos - mercadorias parecidas quanto ao seu uso básico, mas diferentes quanto às suas amplificações de troca de funcionalidades e desejos agregados. Evidentemente, o produto de última geração deve ter um preço diferenciado, que o destaque dos demais. Afinal, o acesso à novidade deve ser na lógica da exclusividade e não da inclusividade. Exclusividade que demarca a fronteira entre aquele que pode e aquele que não pode.

Entre aquele que tem e aquele que não tem. Entre o reconhecido e o não reconhecido. Assim, com a obsolescência da técnica, o que era considerado luxo passa, paulatinamente, por um desnatamento até sua condição de lixo para a classe dos inovadores. Neste ciclo, a diferenciação econômica de exclusão se reafirma, com o reforço de tais práticas de produção, circulação e consumo.

\subsection{A publicidade na mídia celular}

No caso dos profissionais de marketing, descobriu-se que, além de uma ferramenta importante para as ações da disciplina, o uso publicitário seria uma possibilidade nova e diferente. E, além disso, auxiliaria justamente nas soluções dos novos desafios da propaganda, especialmente por um aspecto: “O celular pode ser uma mídia com dupla função: ser considerada de massa, porque pode atingir um grupo grande de consumidores com características semelhantes, como também desenvolve o chamado Marketing One-toone $e^{6}$ - compreendido como marketing de corpo a corpo, com respostas e reações rápidas de um consumidor para com os atributos do produto ou da promoção planejada.

O marketing One-to-one (um a um) aborda formas de relacionamento individualizadas. Ao compreender a necessidade de cada pessoa, de acordo com seu histórico de compra ou mesmo pelos sites que acessa, as empresas passam a oferecer o que pode interessar ao consumidor, obtendo maior retorno e estabelecendo um relacionamento

\footnotetext{
${ }^{6}$ Palestra: Andrea Ortenzi, “A publicidade no Celular” 30 de setembro de 2004, II tela viva móvel.
} 
com efeitos de sentido considerados menos abusivos, em que as mensagens alcançam o público essencial.

O Mobile Marketing (ou marketing móvel) é uma nova forma de pensar estratégias, que, basicamente, utiliza-se de telefones celulares, PDA's e Smartphones ou as chamadas tecnologias móveis - para transmitir, em um primeiro estágio, mensagens de textos (SMS). Mas já são encontradas mensagens multimídia (MMS), entre outras formas, que podem funcionar como ações promocionais, propagandas, relacionamento junto aos clientes, parceiros, negócios, convite para eventos, e também ações de marca (Branding). Nesse âmbito, o celular é o canal ou a mídia, enquanto a forma e as estratégias ficam para o Mobile Marketing.

As evoluções ainda permitem, em alguns países e no Brasil, o uso publicitário da internet via celular, jogos patrocinados, vídeos publicitários, músicas, localização via GPS, os quais formam uma cadeia de valor complexa e que fazem desse canal uma das grandes promessas da nova forma de conduzir o Marketing e a Propaganda, em geral.

A novidade é distribuir essas mensagens de forma personalizada, direta e interativa, estabelecendo um contato bidirecional com cada um dos receptores. Além de trabalhar com um banco de dados e informações específicas e pessoais dos usuários, a tecnologia permite certo controle das mensagens que foram enviadas, as que foram lidas, verificando o retorno da campanha ou ação. Sob tal personalização, ainda é possível definir e programar os envios das mensagens para determinados horários, com dias e meses de antecedência.

Outra aplicação do Marketing móvel é que essa modalidade possibilita estratégias que conduzem o receptor à ação (call to action). Pode-se citar, por exemplo, a situação em que, ao receber a mensagem, o cliente ou consumidor responda via SMS mesmo, até situações novas, como aquelas em que para participar de determinada promoção o usuário deve scanear ou fotografar o código de barras do produto de determinada marca e enviar via celular a imagem para o número da empresa, concorrendo automaticamente a alguma promoção, podendo ganhar prêmios ou brindes.

Portanto, a mídia celular, segundo referenciais mercadológicos, permite:

- Comunicação -"qualquer hora" e "qualquer lugar" (anytime - anyplace);

- Interação e envolvimento - possibilidade e desejo de se comunicar de forma individualizada e direta um a um. A chamada comunicação de duas vias, gerando interações imediatas;

- Mídia única - no composto de comunicação, promoção, branding e relacionamento, totalmente baseada na permissão do usuário. Grande 
penetração. No Brasil, apresenta capacidade única de atingir o público, classe $\mathrm{C}$, dos 15 aos 30 anos, além das classes A e B.

- Bancos de dados - empresas desejam utilizar-se de telefone celular para atingir os clientes certos.

- Localização - LBS (Location Based Services) -a propaganda móvel (mobile advertising) pode ser aplicada em uma audiência definida, localizada geograficamente ou por áreas de interesse, além de poder se utilizar do serviço de páginas amarelas e mapas de localização.

- Personalização - as mensagens podem ser personalizadas, ou seja, o nome do consumidor, telefone, área em que mora e outras informações podem ser utilizadas para comunicar diretamente ao público;

- Interação - o Mobile Marketing serve como complemento para as ações tradicionais de marketing e para as mídias tradicionais;

- Operadoras - interesse em aumentar suas receitas com campanhas de marketing de grandes marcas.

\subsection{Estratégias e usos}

Sendo uma Mídia Nova, o celular apresenta diversas controvérsias e, ao mesmo tempo, situações ainda consideradas inexploradas pelos marketeiros. No entanto, é possível se delinear como este canal vem sendo utilizado não apenas para ações de marketing, mas também como uma opção de mídia publicitária.

A seguir, são apresentadas as principais aplicações do Mobile Marketing ou Marketing Móvel.

- Branding - Ações de Marca:

Este conceito basicamente busca formas de comunicação e relacionamento junto aos efetivos e possíveis clientes. Aumentar a consciência de marca (awareness), por exemplo. A importância da marca surge nesse contexto em que diversos produtos apresentam características técnicas (de produção) muito similares, portanto o "DNA" da marca ou a idéias que esta transmite são verdadeiros diferenciais e determinantes da ação de consumo. O Mobile Marketing permite formas interativas e diferentes de relacionamento de marca. São jogos patrocinados, pesquisas, perguntas e respostas, músicas. Por exemplo:

- AdverGames: jogos que funcionam como estratégias de relacionamento e 
divulgam mensagens publicitárias aos usuários. Funcionam basicamente para aumentar a consciência de marca, ao mesmo tempo em que atraem a percepção do consumidor.

-Business Games: jogos e desafios que funcionam para educar, simular e gerar motivação nas equipes de trabalho.

Um exemplo foi a primeira campanha realizada pela $M T V$ da Inglaterra, desenvolvendo um jogo de perguntas e respostas (quiz), cujo objetivo era aumentar a consciência de marca de um dos seus programas. A resposta foi em torno de $16,5 \%$ do total da base de usuários (database) que receberam a mensagem.

No caso do público jovem, há grande consumo de videoclipes, vídeo tones, entrevistas, shows, ringtones, truetones (sons para celular), fotos de artistas, wallpapers (papéis de parede) e Screensavers (proteções de tela).

Outra possibilidade é, por meio dos serviços de localização e demográfico, trabalhar com linguagens e abordagens mais condizentes com o público, utilizando-se de formas de tratamento e opções pessoais. Eventos específicos, ações exclusivas e a utilização das chamadas "infortainement" (Informação e entretenimento) como aviso sobre datas especiais e oferecendo opções para presentes constituem-se em diferenciais que predispõem o consumidor a adquirir os produtos/serviços.

- Promoção de vendas e Marketing Direto

A promoção de vendas ${ }^{7}$ funciona basicamente como forma de incentivo, na maioria das vezes a curto prazo, para experimentação ou compra de um produto. Já o Marketing Direto é a utilização de canais para comunicar diretamente com clientes específicos (Kotler 2000). Apesar de representarem diferentes ferramentas do Mix de comunicação, no caso do Mobile Marketing diversas estratégias são consideradas comuns às duas áreas. Praticamente estas ações envolvem bônus, cupons e descontos.

-Call-to-action (chamar para a ação) - são estratégias de respostas diretas ou concursos e sorteios específicos. O usuário pode receber desde um convite para o lançamento de um produto até cupons e mensagens sobre promoções relâmpago. Do ponto de vista estratégico, podemos comparar o celular e outras mídias, sendo essa a característica mais marcante do canal.

-LBS - As ações e promoções baseadas em serviço de localização e base de dados são as maiores possibilidades. Ao se cadastrar gratuitamente no serviço, o usuário, adentrando o ambiente do shopping, recebe informações e cupons de descontos em

\footnotetext{
${ }^{7}$ Amostras, cupons, reembolso, descontos, brindes, prêmios, recompensas, testes gratuitos, garantias, promoções combinadas, promoções cruzadas, displays ponto-a-ponto e demonstrações.
} 
determinadas lojas que sejam de seu interesse.

Há também cupons que podem ser distribuídos para amigos e outras pessoas, denominados "pass along", com validade pré-estabelecida e que desenvolvem o marketing viral.

Algumas campanhas em outros países apontaram para a eficiência das ações demográficas, em que foi possível aumentar as vendas e obter respostas mais significativas quanto ao perfil dos usuários e necessidades reais por região. As empresas encontraram uma forma de perguntar ao cliente o que este realmente deseja.

Dentre as diversas estratégias nesta área, a que mais tem chamado a atenção e que, inclusive, é considerada a de maior retorno para as ações de marketing é o uso integrado do Mobile com as mídias tradicionais. No Brasil, pode-se citar novamente o exemplo do BBB5 - Big Brother Brasil, programa da rede Globo de Televisão em que algumas pessoas ficam confinadas em uma casa durante alguns meses. Nessa ocasião, foi desenvolvida uma série de ações através desse canal. A operadora "Oi", além da possibilidade de votação via SMS, desenvolveu canais como o BIGspy, BIG Quiz, BIGPerfil, Big Recado e o Chat BBB, em que as pessoas poderiam ouvir tudo o que acontecia durante o programa, testar os conhecimentos sobre os participantes, conversar com o eliminado da semana, saber mais sobre os participantes e até deixar um recado para qualquer um deles. Ou seja, a mídia possibilitou a extensão dos ganhos e permitiu interatividade com o público.

- Event Marketing - Marketing de eventos ou de competição:

Nenhuma hora é melhor para ganhar a atenção dos consumidores do que quando estes estão relaxando ou participando de algum evento. Em shows, eventos esportivos, congressos e feiras, o usuário pode contar com serviços móveis que vão desde descontos específicos para o evento até listas com a programação, mapas, informações adicionais, atendimento ao consumidor, um canal para reclamações, elogios, recomendações ou mesmo pesquisas curtas, que facilitem a vida do usuário ou permitam uma experiência positiva no local.

No lado do negócio, as companhias podem usar promoções móveis para atrair participantes para exposições ou experimentações de amostras. No caso de reuniões ou palestras, o usuário pode contar com um serviço de alerta, caso deseje, confirmando horários e os assuntos abordados.

- CRM (Custumer Relationship Management) Gerenciamento de Relacionamento com o Consumidor.

A natureza interativa e pessoal dos dispositivos móveis faz deste o veículo ideal 
para ampliar relacionamentos existentes junto ao cliente. Muito mais do que apenas mensagens incorporadas em um sentido único do marketing, o Marketing Móvel fornece uma chance para a captação de usuários e serviços valiosos, em um diálogo de duas vias. As companhias podem hospedar um canal móvel próprio para fornecer aos clientes desde informações promocionais, como também para fixar as relações e aspectos de lealdade e sustentação da marca. O Mobile Marketing funciona muito bem para ações de retenção e fidelização de clientes.

A American Airlines fornece um exemplo bom de CRM móvel para aumentar a lealdade do cliente. Além de um canal contendo informações específicas, a empresa percebeu, nesse meio, uma oportunidade para conhecer melhor o perfil desses consumidores. Os usuários podem usar um canal móvel de Internet para programações do vôo, escolha dos lugares, detalhes em fatores especiais, números importantes do contato e até acompanhamento de pontos ou milhas dos programas de relacionamento. Esse é apenas um exemplo das infinitas possibilidades. Nesse meio as estratégias de comunicação misturam entretenimento, informação, venda, relacionamento, posicionamento e ação.

No entanto, como um dispositivo ou uma tecnologia, o celular apresenta formatos pré-estabelecidos os quais geram oportunidades e limitações aos profissionais de comunicação.

- Micro-propaganda via SMS, Ringtones, MMS ou WAP. (DELEON 2004) - SMS (Short Message Service):

São as mensagens de texto ou sem texto (non-text), com limite de 160 caracteres. É a forma mais utilizada para as estratégias de Mobile, pois apresentam um custo relativamente baixo. No Brasil, de acordo com a operadora e o volume de mensagens compradas para uma campanha de comunicação, este valor varia entre $\mathrm{R} \$ 0,20$ e $\mathrm{R} \$ 0,30$ por mensagem; além disso, é um serviço amplamente conhecido pela base de usuários.

Por exemplo: a TIM vende às empresas softwares que possibilitam o envio de 100 mil mensagens a um custo de 18 centavos cada. Já a VIVO definiu um contrato com o Banco do Brasil para oferecer aos clientes operações bancárias via celular. O usuário pode realizar qualquer operação. A operadora, neste caso, recebe em torno de $\mathrm{R} \$ 0,4$ por transação.

Em relação à Propaganda, o SMS apresenta características fundamentais:

- $\quad$ Preço: é mais barato que voz e exige pouco do tráfego de bandas;

- Conveniência: entrega garantida, pois mesmo que o aparelho esteja desligado, o usuário recebe a mensagem depois; 
- $\quad$ Flexibilidade: SMS pode ser encaminhado para apenas um aparelho ou para diversos receptores, podendo ser usado na forma de marketing viral também, em que o usuário pode encaminhar a outros;

- Mensurabilidade: a possibilidade de saber quais mensagens foram realmente recebidas. Algumas práticas já estabelecidas:

- $\quad$ TV - voto estimulado: interação entre usuários e programas de TV, sendo aqueles estimulados para participar de decisões importantes ou proceder a escolhas dentre várias opções através de votos. Um exemplo foi o programa América Idol, que via SMS movimentou mais de 14 milhões de votos nos Estados Unidos;

- Alertas: serviços em que o consumidor recebe mensagens informando sobre lançamentos ou novidades sob determinado assunto ou confirmando compra de passagens, horários de vôo e até mesmo confirmação de pedidos;

- Peça uma canção: o usuário pode escolher uma música em uma lista que recebe diariamente, de acordo com seu interesse;

- Leilão móvel: através das mensagens os usuários fazem lances em tempo real.

- Vendas instantâneas: por meio de localização de usuários ou mesmo promoções relâmpagos, como por exemplo: "os 100 primeiros que vierem ao McDonalds terão $30 \%$ de desconto em qualquer pedido".

Outras formas de aproveitar o SMS são através das chamadas Non Text (sem texto), mensagens utilizando uma combinação de melodias simples (ring tones) a gráficos simples (preto e branco).

Existem ainda os Cupons-Tela, transmitidos no formato de imagem WBMP (Wireless Bitmap). Este é um formato que usa uma codificação binária de compactação de arquivo, deixando-o com um tamanho reduzido. Hoje são encontrados programas que convertem arquivos comuns de imagem como GIF, BMP e JPG em WBMP. Nesse sentido, alguns softwares já foram desenvolvidos exclusivamente para conteúdos em celular, como os WAPDRaws, que auxiliam na construção de imagens monocromáticas.

\section{- Ringtones Publicitários}

Propaganda através de sons, jingles ou slogans verbais, a qual pode ser convertida em ringtones e transmitida. Hoje, com a multifuncionalidade tecnológica, estão disponíveis diferentes formatos como o MP3, WAV e MIDI. Artistas, bandas e gravadoras promovem seus trabalhos através de demonstrações gratuitas, partes de músicas ou mesmo vendas de sons. 
- MMS (Multimídia Message Service)

Serviços de mensagens multimídia disponível em alguns aparelhos, principalmente os de Terceira Geração (3G). Apesar de representarem hoje uma pequena porcentagem do total de usuários (menos de 10\% dos telefones brasileiros) e exigirem muito das bandas de transmissão, serão uma boa opção para o futuro. Vídeos publicitários, jogos patrocinados de boa qualidade visual, filmes em animação (flash). Na Coréia do Sul, por exemplo, há uma empresa que faz novelas de 15 minutos para serem assistidas apenas através do celular. Portanto, nesta gama de opções tecnológicas e de conteúdo multimídia como serviços de som, imagem, voz e ainda transmissões de televisão via satélite, está se desenvolvendo uma nova possibilidade de negócio.

Nesse mesmo sentido, as câmeras fotográficas e de vídeo já presentes em alguns aparelhos são uma grande promessa para a comunicação e interação ao consumidor. Hoje, no mundo, já existem cerca de 80 milhões de telefones celulares com câmeras, que, além de gravar, enviar e receber imagens e áudio, constituem uma representativa economia de tempo e dinheiro em algumas atividades de negócios, o que vem atraindo muitas empresas. Além disso, esta tecnologia permite inúmeras outras aplicações, como, por exemplo, aquelas que permitem imagens em tempo real na compra e venda de imóveis, serviços de consultoria em problemas de arquitetura e até consultoria de moda.

A Operadora TIM apresenta um caso de sucesso na TIM Itália, utilizando o MMS. Denominado TIM SPOT, trata-se de um serviço gratuito de notícias via SMS com 95 caracteres, sendo que no começo da mensagem é mostrada uma propaganda de 55 caracteres. São mais de 2.700 .000 (dois milhões e setecentos mil) clientes cadastrados em 6 diferentes canais, que recebem duas vezes por semana um SMS só de advertising.

Outro exemplo, o TIM Spot Meteo, é um serviço que conta com cerca de 23.000 assinantes que, a cada sexta-feira, recebem informações sobre a previsão do tempo para o final de semana. Uma vez por semana é enviado um MMS Promocional só com advertising. No caso, o MMS é composto de 8 frames: os frames 2 e 7 são de advertising e os demais são para abertura, conteúdo da notícia e fechamento.

Outras ações:

-Hot Code: são códigos impressos em embalagens, anúncios publicitários, institucionais e cartões de visita. O usuário, ao passar a câmera do celular sobre o código automaticamente é direcionado para uma página com informações adicionais.

- $M$ - commerce: além das compras de conteúdo e serviços de banco e informação, o usuário poderá fazer micro-pagamentos ao passar o telefone em um leitor de máquina de 
refrigerante ou caixas eletrônicos o valor da compra é debitado em conta específica do banco ou mesmo no cartão de crédito.

- WAP (Wireless Acess Protocol)

É um sistema que apresenta diversas possibilidades de conteúdo e interação. Basicamente o WAP é o primeiro passo para a internet no celular. Na verdade são canais específicos acessados via operadora. Existem aparelhos que já possuem acesso à internet $\mathrm{e}$ outros suportam linguagens e programação comuns à web. No entanto, as questões do formato e do volume de informações ainda restringem o serviço. Uma alternativa interessante na hora de desenvolver o site para internet pode facilitar a transição. Recomenda-se a construção das páginas com uma técnica denominada Tableless (sem tabelas), em que o conteúdo é separado da parte visual, do design ou diagramação. Ao carregar o conteúdo no celular, este se adapta à plataforma, inclusive dando aos usuários mais opções em relação aos tipos de fonte, cores e até necessidades especiais. Os portais Wap apresentam serviços de interação e agregam valor para os serviços das operadoras.

Portanto, se por um lado estes diferentes formatos condicionam a forma de desenvolver a publicidade e o marketing, por outro permitem a percepção de um modelo de negócio para a publicidade no celular, muito próximo daquele que algumas operadoras já estão utilizando e que segue as seguintes etapas:

- um Cliente se cadastra e aceita receber advertising diretamente no celular;

- as mensagens de advertising, vendidas através de uma agência de propaganda, são enviadas ao Cliente;

-sendo que o valor da impression está diretamente relacionado à qualidade do data base de usuários;

-como vantagem, o Cliente, em troca de receber mensagens de advertising, recebe, gratuitamente, serviços, recarga de crédito e outros benefícios da operadora.

\section{A CONVERGÊNCIA E IMPLICAÇÕES SOCIAIS}

Podemos considerar que o celular é uma nova modalidade midiática, capaz de convergir diferentes mídias numa única proposta agregada. Seria o fim do termo multimídia na literatura especializada? Percebe-se, assim, uma força centrípeta no celular, fornecendo, na mobilidade humana, a possibilidade de o sujeito consumidor carregar os aparelhos de lazer e de entretenimento no seu bolso ou em algum espaço de sua indumentária. 
A força centrípeta do celular vai além da convergência de mídias. Ela também unificou, de certo modo, nossas extensões dos sentidos - da visão e audição. O que antes a TV propiciava o equipamento também proporciona, embora em tamanho reduzido. $\mathrm{O}$ telefone convencional, demarcado por uma delimitação espacial, agora atravessa fronteiras geográficas, juntamente com nosso deslocamento corporal.

Por outro lado, observamos e sentimos uma força centrífuga, neste processo. Uma força desagregadora, que contribui para o reforço da exclusividade. A exclusividade se choca com o potencial inclusivo. Dessa maneira, ações de marketing corroboram o efeito de exclusão social, pois é por meio do mix de produtos, juntamente com suas potencialidades de operacionalização e de novidades de informação e entretenimento, que os produtos, com atributos diferenciados, agregam-se aos possíveis anseios da diferenciação humana. A exclusão, mediante tal processo, é perceptível nas ações que a lógica do modo de produção capitalista, aliado à tecnologia, pode proporcionar. Isso porque nos parece que ao componente do desejo de diferenciação, outro desejo é latente: a busca por identidade. Nessa proposta de acreditar na busca e procurar sua operacionalização, a diferenciação é marcada pela negatividade do outro, do alter, da alteridade.

O que era luxo para alguns se torna lixo e, paradoxalmente, luxo para outros novamente. A estratificação social é um dos efeitos da força centrífuga do celular. Alguns segmentos sociais podem, por exemplo, adotar uma perspectiva identificatória para com suas potencialidades de ganho salarial, diferenciando-se de outras por meio do consumo estratificado e técnico dos aparelhos. Nessa compartimentação e centrifugação, expande-se também o capital do anunciante. Entretanto, não mais como algo pertencente ao mesmo, pois formas regulatórias condicionaram certa independência para que o mesmo fosse considerado simples objeto. Ele se constitui como elemento alheio à subjetividade humana, adquirindo assim, força vital para mobilizar as massas na busca de suas extensões corpóreas no espaço e no tempo.

\section{CONSIDERAÇÕES (IN)CONCLUSIVAS}

Neste artigo, procuramos, num primeiro momento, apresentar elementos descritivos, mercadológicos e técnicos relacionados à mídia celular. Foi importante explorarmos considerações operacionais, pois a análise da técnica pode proporcionar a revelação das significações adjacentes do processo tecnológico implícito e sua relação com o modo de que o homem se comunica com os produtos e suas amplificações de sentido na 
cultura e sociedade.

Toda inovação técnica pode acarretar espanto, admiração, curiosidade ou resistência em segmentos sociais diversos. São diversas as variáveis que podem influir nas percepções dos possíveis consumidores de novas tecnologias. De modo semelhante, pudemos observar tais inquietações com o advento das mídias eletrônicas: o rádio, a televisão no século XX e, recentemente, a popularização da internet. Atualmente, a mídia celular se apresenta como elemento de convergência de meios eletrônicos com a qualidade móvel, acompanhando a corporalidade humana em seus deslocamentos espaciais. Entretanto, sob um viés teóricocrítico, salienta-se que a introdução de novidades hi-tech nos mercados perpassa intencionalidades lucrativas dos anunciantes e coadjuvantes do processo circulatório do capital junto aos atores envolvidos na esteira da produção e do consumo. A estratificação social aliada à possibilidade segmentada de atribuir qualidades diferenciadas, segundo incrementos técnicos no produto celular, condiciona maior ciclo de vida para a mercadoria, objeto da planificação estratégica dos profissionais de marketing de empresas/indústrias e de agências de publicidade. Para que o produto celular, após uma fase de crescimento no mercado, pudesse atingir um estágio considerado de maturidade, os atributos funcionais convergentes de outras mídias foram possibilitados para o prolongamento de seu ciclo de maturidade. Isso porque, segundo literatura especializada em marketing, é na maturidade que o produto propicia maior rentabilidade à indústria. Prolongar tal fase, conjugando táticas de estratificação e segmentação de mercado, pode ser uma das estratégias para estabelecer uma biografia estendida do produto, junto a classes de consumidores variados na sociedade.

Considerando-se tais aspectos, destacamos, num primeiro momento, a importância de descrever, analiticamente, as práticas atualmente empregadas, bem como tendências esperadas junto ao uso e penetração da mídia celular no universo publicitário e de possíveis consumidores do produto. Em uma segunda etapa, levantamos algumas inquietações sociais, considerando seus efeitos e reflexos na sociedade da informação e do consumo. Como toda nova proposta carece de reforço crítico e reflexivo, deixamos uma breve contribuição para os interessados no tema e consideramos a tarefa inconclusiva, pois suas conseqüências e efeitos de sentido refletem e refratam os conflitos advindos da experimentação nos grupos sociais diversos.

\section{REFERÊNCIAS BIBLIOGRÁFICAS}


ANATEL. Comunicação Móvel. Disponível em <http://www.anatel.gov.br> Acesso em: 15 de set. 2005. ANATEL. Pesquisa sobre consumo e qualidade no serviço. SMC/SMP, 2003.

A TARDE ON LINE. A história do celular no Brasil. Disponível em http://www.atarde.com.br/especiais/telefoniamovel/mat_historico.php. Acesso em 18 out. 2005.

CAPPO, J. O futuro da Propaganda: Nova mídia, novos clientes, novos consumidores na era pós televisão. São Paulo, Cultrix, 2003.

CITELLI, A. Linguagem e persuasão. São Paulo, Ática, 1985.

DELEON, B. Marketing on the go: using mobile phones to promote and market your product or service. Flórida, DGXMEDIA, 2004.

DIZARD, W. A nova mídia: a comunicação de massa na era da informação. 3 ed. Rio de Janeiro, Zahar, 2000.

EMPOCKET. MOBILE MARKETING/Empocket Solutions, Engine e SMS writer Disponível em <http://www.enpocket.com > Acesso em: 07 de ago. 2005.

GÜNTHER, H. Celular ou não celular? Disponível em <http://www.unb.br/acs/artigos > Acesso em: 10 de set. 2005.

HAIG, M. Mobile Marketing: the message revolution. UK, Kogan Page, 2002.

HAUG, F. Crítica da Estética da Mercadoria. Trad. Erlon J. Paschoal. São Paulo, Unesp, 1996.

HOHLFELDT, A. et al. (org). Teorias da Comunicação. Petrópolis, Vozes, 2002.

INFO EXAME. Tudo sem fio: como as tecnologias wireless estão implodindo a ditadura dos cabos. $\mathrm{n}^{\circ}$. 231, ano 20, São Paulo: Abril, 2005.

JHALly, S. Os Códigos da Publicidade. Trad. Ângela Maria Moreira. Porto, Asa, 1995.

KATZ, H. Media Handbook: um guia completo para eficiência em mídia São Paulo, Nobel, 2004.

KOTLER, P. Administração de Marketing: a edição novo milênio. São Paulo, Prentice Hall, 2000.

KOTLER, P. Marketing para o século XXI: como criar, conquistar e dominar mercados. São Paulo, Futura, 1999.

LAS CASAS, L. (Coord.). Novos rumos do Marketing São Paulo, Atlas, 2001.

LEVITT, T. Marketing Myopia. Harvard Business Review, vol. 38: 45-56, July/August 1960. 
MAINGUENEAU, D. Termos Chaves da análise do discurso. Belo Horizonte, UFMG, 2001.

MCLUHAN, M. The medium is the message: an inventory of. effects. San Francisco, HardWired,1996.

O’GUINN,T, ALLEN, C \& SEMENIK, R. Advertising. Southwestern College Publishing USA, 2000.

PIMENTEL, P. Celular não é telefone, mas aparelho multimídia móvel. Jornal Gazeta do Povo. Caderno Economia. Curitiba. 29 de maio de 2005, p. 3.

PINTO, J.M.. Comunicação e Discurso. São Paulo, Hacker, 1999.

RHEINGOLD, H. Smart Mobs: the next social revolution. Perseus Publishing, 2002.

SALZMAN, M., MATATHIA, I. \& O’ REILLY, A. Buzz: a era do marketing viral como aumentar o poder da influência e criar demanda. São Paulo, Pensamento, 2003.

SANT`ANNA, A. Propaganda: teoria, técnica e prática. São Paulo, Pioneira Thomson Learning, 2002.

SCHIESEL, Seth. A $3 G$ enfim chega ao consumidor nos EUA. Jornal Gazeta Mercantil. Brasília, 15 de fevereiro de 2005.

III TELA VIVA MÓVEL. Encontro dos serviços e entretenimento wireless. São Paulo, Abril de 2005.

TELECO. Telefonia celular. Disponível em <http://www.teleco.com.br> Acesso em: 9 de agosto. 2005.

Artigo recebido em 21/3/2009.

Aprovado em 29/4/2009. 